\title{
Editorial \\ Serum urate, menopause, and postmenopausal hormone use: from eminence to evidence-based medicine
}

\author{
Angelo L Gaffo ${ }^{1}$ and Kenneth G Saag ${ }^{2}$
}

\author{
${ }^{1}$ Birmingham VA Medical Center, 700 19th Street South, Birmingham, AL 35233, USA \\ 2Division of Clinical Immunology and Rheumatology, University of Alabama at Birmingham, FOT 820, $15303^{\text {rd }}$ Avenue South, Birmingham, AL 35294, USA
}

Corresponding author: Kenneth G Saag, ksaag@uab.edu

Published: 17 October 2008

This article is online at http://arthritis-research.com/content/10/5/120

Arthritis Research \& Therapy 2008, 10:120 (doi:10.1186/ar2524)

c) 2008 BioMed Central Ltd

See related research article by Hak and Choi, http://arthritis-research.com/content/10/5/R116

\begin{abstract}
The relationship between serum urate, menopause, and aging has not been clearly defined by scientific evidence. In the present issue of Arthritis Research and Therapy, Hak and Choi present a crosssectional analysis to clarify the effect of menopause and hormone replacement therapy on serum urate in women within the Third National Health and Nutritional Examination Survey. Menopause increased serum urate and hormone replacement therapy significantly decreased serum urate, although the overall level of change was small. The implications of these urate changes on gout and cardiovascular disease outcomes require further study.
\end{abstract}

In the past era of predominately opinion-based or eminencebased medicine, the relationship between serum urate, sex, and aging has always been perceived by astute clinicians to be a rather simple one; namely, women have lower levels of serum urate than men, and have a lower prevalence of gout. In women, serum urate levels increase with aging and the onset of menopause until the levels roughly equal those of men in later years - this is the traditional view being revised in the present issue of Arthritis Research and Therapy by Hak and Choi's study [1].

Menopause and hormone replacement therapies, possibly mediated by steroid hormones inducing a more efficient renal uric acid excretion, are thought to influence the age-related phenomenon of changes in women's serum urate [2-5]. The impression of a simple relationship between sex, menopausal status, and serum urate has not been particularly evidencebased, however, given the lack of large studies in which there was adequate control for confounding factors known to affect the serum urate and menopausal status. Uncovering the true effect of these relationships has significant relevance not only for rheumatologists who treat gout but also for all physicians, given increasing data on the association of serum urate with adverse cardiovascular outcomes among postmenopausal women [6].
In this context, Hak and Choi present data from a large and representative sample of 7,662 women in the United States the Third National Health and Nutritional Examination Survey [1]. Using a cross-sectional design, the study evaluates the relation between menopause (natural and surgically induced), postmenopausal hormone use, and serum urate levels.

The main strength of the study is its careful methodology, including a thorough assessment of potential confounders such as age, body mass index, medication use, comorbidities, and dietary factors. After multivariate adjustment, menopause was found to significantly increase serum urate levels (by $0.34 \mathrm{mg} / \mathrm{dl}$ and $0.36 \mathrm{mg} / \mathrm{dl}$ in women with natural menopause and with surgical menopause, respectively, when compared with premenopausal women) [1]. The results of the study did not vary substantially after excluding those women who reported having gout or who were taking common uratelowering drugs, or even among subgroups defined by body mass index, hypertension, or alcohol use.

The authors also found significantly lower multivariableadjusted serum urate among postmenopausal women that were current users and past users of hormone replacement therapy when compared with never users (decreases of $0.26 \mathrm{mg} / \mathrm{dl}$ and $0.15 \mathrm{mg} / \mathrm{dl}$ in current users and past users, respectively) [1]. Finally, the linear trend of age in association with serum urate levels among postmenopausal women was significant after adjusting for menopausal status, but this trend was attenuated to nonsignificance after including renal function in the statistical model.

Despite its size, elegant methodology, and generalizability, a limitation of this study is its cross-sectional nature, which cannot completely disentangle the temporal sequence of events supposedly leading to an elevation in serum urate. The study further assumes that findings in a group of pre- 
menopausal women are adequate controls for a different group of postmenopausal women.

These interesting results obtained by Hak and Choi are concordant with those published by Simon and colleagues using data from the Heart and Estrogen-Progestin Replacement Study. In that study, the serum urate decreased by a mean of $0.20 \mathrm{mg} / \mathrm{dl}$ among postmenopausal women after taking combination hormone replacement therapy for 1 year [7]. Their study and other smaller previous studies, however, only assessed the changes in serum urate induced by hormone replacement therapy. Hak and Choi's study additionally offers the first controlled attempt to describe the association of natural and surgical menopause with serum urate.

The clinical relevance of the findings of Hak and Choi's paper can be considered from different perspectives. Clinicians with an interest in the effect of hormonal factors on gout incidence could find the increases in serum urate induced by menopause and the protection conferred by hormone replacement therapy too modest to be of very much clinical relevance. Using data available for men from the Normative Aging Study as a comparison, the cumulative incidence of gout significantly increased only after reaching a serum urate level of $9.0 \mathrm{mg} / \mathrm{dl}$ or more $(4.5 \%$ per year versus $0.5 \%$ per year when serum urate was between 7.0 and $8.0 \mathrm{mg} / \mathrm{dl}$, and $0.1 \%$ per year at urate levels $<7.0 \mathrm{mg} / \mathrm{dl}$ ) [8]. The serum urate levels from the Normative Aging Study are significantly higher than those routinely seen in premenopausal women (a mean of approximately $3.2 \mathrm{mg} / \mathrm{dl}$ ) [5]. Factors other than menopause, such as genetics, diet, medication use, comorbidities, or unknown environmental factors, must therefore also be invoked to explain the well-described increase in gout prevalence for women at older ages $(<5 \%$ of all gout cases at ages 30-39 years overall occur in women, compared with $25-50 \%$ at ages $>60$ years [9]).

While the implications of the small increases in serum urate found in this study are still unknown two previous studies offer potential insights. Using a composite of cardiovascular outcomes including death, acute myocardial infarction, stroke and congestive heart failure, Strasak and colleagues reported a hazard ratio of 1.10 (95\% confidence interval, 1.06 to 1.13 ) with each milligram per deciliter of increase in serum urate among 28,613 older postmenopausal women followed for 21 years [6]. In contrast, Simon and colleagues did not find an association between serum urate levels and the risk for coronary heart disease events. There was no protection conferred by the minor reduction in serum urate induced by estrogen and progestin replacements [7]. One might infer from these results that the increase in serum urate of 0.34 to $0.36 \mathrm{mg} / \mathrm{dl}$ seen in Hak and Choi's study may not be enough to significantly augment the risk for cardiovascular disease per se.

In summary, the article by Hak and Choi contributes a valuable piece of information to the literature about the association of serum urate with menopause and postmenopausal hormone replacement therapy. Additional studies are needed to explain the mechanisms for these increases in serum urate seen in older women. Finally, inferences about the ultimate impact these urate changes may have on gout and cardiovascular disease will need to be tested or confirmed in longer, larger, and prospective studies. Studies such as the one presented in the current issue of Arthritis Research and Therapy make us realize that uncovering the true nature of apparent simple observations long held true in medicine is seldom straightforward.

\section{Competing interests}

ALG declares that they have no competing interests. KGS is a consultant for and received research grants from TAP, Savient, and Merck.

\section{References}

1. Hak AE, Choi HK: Menopause, postmenopausal hormone use, and serum uric acid levels in US women - The Third National Health and Nutrition Examination Survey. Arthritis Res Ther 2008, 10:R116.

2. Adamopoulos D, Vlassopoulos C, Seitanides B, Contoyiannis P, Vassilopoulos P: The relationship of sex steroids to uric acid levels in plasma and urine. Acta Endocrinol (Copenh) 1977, 85:198-208.

3. Nicholls A, Snaith ML, Scott JT: Effect of oestrogen therapy on plasma and urinary levels of uric acid. Br Med J 1973, 1:449-451.

4. Sumino H, Ichikawa S, Kanda T, Nakamura T, Sakamaki T: Reduction of serum uric acid by hormone replacement therapy in postmenopausal women with hyperuricaemia. Lancet 1999, 354:650.

5. Wingrove CS, Walton C, Stevenson JC: The effect of menopause on serum uric acid levels in non-obese healthy women. Metabolism 1998, 47:435-438.

6. Strasak AM, Kelleher CC, Brant LJ, Rapp K, Ruttmann E, Concin $\mathrm{H}$, Diem G, Pfeiffer KP, Ulmer H: Serum uric acid is an independent predictor for all major forms of cardiovascular death in 28,613 elderly women: a prospective 21 -year follow-up study. Int J Cardiol 2008, 125:232-239.

7. Simon JA, Lin F, Vittinghoff E, Bittner V: The relation of postmenopausal hormone therapy to serum uric acid and the risk of coronary heart disease events: the Heart and EstrogenProgestin Replacement Study (HERS). Ann Epidemiol 2006, 16:138-145.

8. Campion EW, Glynn RJ, DeLabry LO: Asymptomatic hyperuricemia. Risks and consequences in the Normative Aging Study. Am J Med 1987, 82:421-426.

9. Lawrence RC, Felson DT, Helmick CG, Arnold LM, Choi H, Deyo RA, Gabriel S, Hirsch R, Hochberg MC, Hunder GG, Jordan JM, Katz JN, Kremers HM, Wolfe F; National Arthritis Data Workgroup: Estimates of the prevalence of arthritis and other rheumatic conditions in the United States: Part II. Arthritis Rheum 2007, 58:26-35. 